\title{
Evaluation of the Effects of Nutritional and Environmental Parameters on Extracellular Protease Production by Stenotrophomonas acidaminiphila Strain BPE4
}

\section{Philomena Effiom Edet' ${ }^{1}$, Atim David Asitok ${ }^{1}$, Maurice George Ekpenyong ${ }^{1}$, Sylvester Peter Antai ${ }^{1}$}

\begin{abstract}
${ }^{1}$ Environmental Microbiology and Biotechnology Unit, Department of Microbiology, Faculty of Biological Sciences, University of Calabar, P.M.B.1115 Calabar, Nigeria

Abstract: An aerobic mesophilic Gram-negative rod-shaped bacterium isolated from fermenting bean processing effluent (BPE) and identified as Stenotrophomonas acidaminiphila strain BPE4, produced an extracellular protease on skimmed-milk minimal medium. Time-course of enzyme production revealed peak productivity at $12 \mathrm{~h}$ but enzyme concentration gradually increased till $36 \mathrm{~h}$ beyond which both concentration and productivity gradually decreased. Evaluation of the influences of major nutritional sources on enzyme concentration revealed significant $(P$ $<0.05)$ effects of fermentation time and nutrient sources, with corn steep liquor and $\mathrm{NH}_{4} \mathrm{Cl}$ emerging as best carbon and nitrogen sources respectively. The study also selected $\mathrm{K}_{2} \mathrm{HPO}_{4} / \mathrm{KH}_{2} \mathrm{PO}_{4}(2: 1)$ and $10^{8}$ cfu/mL as most appropriate phosphate combination and inoculum size respectively for maximum release of protease within the fermentation time of $36 \mathrm{~h}$. One unit of proteolytic activity was defined as the amount of crude enzyme that digested $1 \mathrm{mg}$ of azocasein in one minute under the assay conditions. Assessment of optimum conditions of temperature and $\mathrm{pH}$ for test enzyme activity revealed optimum enzyme activity of $158.83 \mathrm{U} / \mathrm{mL}$ (2647.70 nkatal) at $40^{\circ} \mathrm{C}$ and $\mathrm{pH} 9.0$ suggesting protease of the alkaline kind. The enzyme was specific for casein as a protein substrate. Stenotrophomonas acidaminiphila strain BPE4 could be exploited for commercial production of extracellular protease on corn steep liquor as a waste management option and industrial applications.
\end{abstract}

Keywords: Stenotrophomonas acidaminiphila; Caseinolytic protease, Production, Corn steep liquor; Environmental factors

\section{Introduction}

Proteases, variously called peptidases or proteinases, are hydrolytic enzymes belonging to the group of hydrolases (EC 3.4.21-24) which catalyze the hydrolytic cleavage of peptide bonds in proteins and polypeptides releasing peptides of shorter lengths and monomeric amino acid units. They are synthesized by all life forms including plants (papain, bromelain and ficin), animals (chymosin, trypsin and pepsin) and microorganisms (subtilisin, bacillopeptidases and aspergillopepsin) $[12,15]$. Proteases perform several physiological roles in producing organisms such as digestion of food proteins, blood clotting, protein turn-over, signal transduction, cell division as well as in the life cycle of organisms $[6,15]$. Majority of these roles form the bases for exploitation of the enzyme in diverse biotechnological concerns including food, pharmaceutical, detergent, waste water treatment, organic synthesis, leather tanning and textile processing [3].

Proteases constitute $60 \%$ of the global enzyme market with current world sale put at 3 billion USD per annum [12] thus making proteases the most sought-after group of enzymes. Microbial proteases, in particular, control a large portion of the protease market owing to the high growth rate, ease of cultivation and propensity for genetic and metabolic manipulation of producing organisms designed for improvement in both quantity and quality [8]. Several microbial genera have been reported as sources of proteases with differing capacities for production. Among them, the genera Bacillus, Pseudomonas, Microbacteria, Vibrio, Streptomyces, Xanthomonas, Aspergillus, Fusarium, Paecilimyces and Cephalosporium are frequently reported $[11,12,16]$.

This article is published under the terms of the Creative Commons Attribution License 4.0

Author(s) retain the copyright of this article. Publication rights with Alkhaer Publications.

Published at: http://www.ijsciences.com/pub/issue/2018-02/

DOI: 10.18483/ijSci.1548; Online ISSN: 2305-3925; Print ISSN: 2410-4477 
The major drawback of large-scale production has been the nature of producing microorganism, availability of utilizable carbon substrates and other major nutritional elements. Environmental factors especially $\mathrm{pH}$ and temperature have been reported for their influences on protease production but more significantly on the activity of the various proteases reported [10].

In this study, we report the potential of Stenotrophomonas acidaminiphila strain BPE4 to elaborate protease and the nutritional and environmental conditions required for production and activity of the enzyme.

\section{Materials and methods \\ 2.1 The microorganism}

The bacterium was isolated in pure culture on tryptic soy agar from a bean processing effluent left untended for 4 days by local bean ball processors in Calabar municipality, Nigeria. The organism was characterized in terms of cultural morphology, microscopy and biochemical characterizations [9]. Molecular characterizations of the bacterium followed DNA extraction, amplification and sequencing as described in [10]

\subsection{Screening procedures for protease production}

\subsubsection{Protease production on solid medium}

The screening medium was skimmed milk-minimal agar medium containing $(\mathrm{g} / \mathrm{L}) \mathrm{MgSO}_{4} .7 \mathrm{H}_{2} \mathrm{O} \quad 0.5$; $\mathrm{K}_{2} \mathrm{HPO}_{4} 1.0 ; \mathrm{KH}_{2} \mathrm{PO}_{4} 1.0$; Skimmed milk $1 \%(\mathrm{v} / \mathrm{v})$; Agar-agar 15; Distilled water $1000 \mathrm{~mL}$; $\mathrm{pH}$ was adjusted to 7.0 with $1 \mathrm{M} \mathrm{HCl} / 1 \mathrm{M} \mathrm{NaOH}$. Minimal medium was sterilized by autoclaving at $121^{\circ} \mathrm{C}$ for 15 min. Skimmed milk was selectively sterilized by filtration (0.45 $\mu \mathrm{M}$-Millipore). Triplicate plates were inoculated by single-line streak technique and incubated at the ambient conditions of the laboratory, specifically room temperature $\left(28 \pm 2^{\circ} \mathrm{C}\right)$ for $36 \mathrm{~h}$. Vibrio fluvialis OWPB63 UCCM 0004 obtained from the University of Calabar Collection of Microorganisms served as positive control. Development of a clear zone around the line of streak on the opaque (cloudy) milk-agar plate indicated protease production. Diameter of clear zone, measured by means of a meter rule and presented in millimeters, was compared with that of the control.

\subsubsection{Protease production in submerged culture} Protease production ability of the bacterium was also assessed in shake flasks using skimmed milkminimal broth medium containing (g/L) $\begin{array}{llllll}\mathrm{MgSO}_{4} .7 \mathrm{H}_{2} \mathrm{O} & 0.5 ; & \mathrm{K}_{2} \mathrm{HPO}_{4} & 1.0 ; & \mathrm{KH}_{2} \mathrm{PO}_{4} & 1.0\end{array}$ Skimmed milk 1\% (v/v); Distilled water $1000 \mathrm{~mL}$; $\mathrm{pH}$ was adjusted to 7.0 with $1 \mathrm{M} \mathrm{HCl} / 1 \mathrm{M} \mathrm{NaOH}$. Minimal medium and skimmed milk were sterilized as earlier described. An 18 h-old tryptic soy broth culture of the bacterium was inoculated into $250 \mathrm{~mL}$ Erlenmeyer flask containing $50 \mathrm{~mL}$ of medium at $2 \%$ $(\mathrm{v} / \mathrm{v})$ and flasks incubated at room temperature $(28 \pm$ $2{ }^{\circ} \mathrm{C}$ ) on a rotary shaker agitating at $150 \mathrm{rpm}$ for $36 \mathrm{~h}$. Protein was detected by the Bradford method as described in [4] bovine serum albumin (Research Organics, USA) as standard protein. A calibration curve was prepared using standard protein with concentrations ranging from 5 to $100 \mu \mathrm{g} / \mathrm{mL}$. Test protease concentration was determined from the regression equation derived from the standard curve.

\subsection{Determination of bacterial productivity of protease}

Time-course of protease production was monitored to determine the protease productivity of the bacterium and to also inform the duration of fermentation studies. Medium formulation, sterilization and inoculation were as described earlier. Incubation was at room temperature on a rotary shaker agitating at $150 \mathrm{rpm}$ for $48 \mathrm{~h}$ with periodic triplicate protein determinations made every $4 \mathrm{~h}$. Fermentation time was extended to $96 \mathrm{~h}$ with triplicate protein determinations made every $12 \mathrm{~h}$. Analysis of variance of data was conducted with Excel 2007 software.

\subsection{Biochemical and molecular characterizations of the bacterium}

Cultural characterizations including consistency, elevation, form, margin and pigmentation; microscopic characterizations including cell shape, size and arrangement; physiological and biochemical characterizations as described in [9] were employed for bacterial identification. Identity of the isolate was confirmed by molecular methods using $16 \mathrm{~S}$ rRNA gene amplification and sequencing.

The molecular methodology was based on PCR and Sanger sequencing analysis. DNA extraction and bioinformatic analysis of sequences were performed at the Molecular Laboratory Services Division of Teddy \& Thaddeus Nig. Co., Akoka, Lagos, Nigeria. Sequencing analysis was done at Inqaba Biotechnology Pty, South Africa. DNA extraction and purification were done using ZR Fungal/Bacterial DNA MiniPrep ${ }^{\mathrm{TM}} 50$ Preps. Model D6005 (Zymo Research, California, USA) using universal degenerate primers 27F.1 Forward 5'AGRGTTTGATCMTGGCTCAG $3^{\prime}$ and 1492R reverse 5' GGTTACCTTGTTACGACTT 3' that amplifies the entire $16 \mathrm{~S}$ variable region at annealing temperature of $58^{\circ} \mathrm{C}$. The PCR cycle started with an initial denaturation step at $94^{\circ} \mathrm{C}$ for $10 \mathrm{~min}$ followed by 30 cycles of denaturation at $94^{\circ} \mathrm{C}$ for $1 \mathrm{~min}$, annealing at $58^{\circ} \mathrm{C}$ for $1 \mathrm{~min}$, extension at $72^{\circ} \mathrm{C}$ for $1 \mathrm{~min}$, an extension at $72^{\circ} \mathrm{C}$ for $5 \mathrm{~min}$ and cooling to $4^{\circ} \mathrm{C}$. Sequence analysis from 
resultant nucleotide base pairs was performed by BLAST analysis using MEGA5 software. The resultant top hits with minimum E-score for the BLAST showing species name was used to identify the specific organism [10].

\subsection{Selection of appropriate major nutritional sources for protease production \\ 2.5.1 Effect of carbon source on protease production}

Six different carbon sources including cassava processing effluent, rice processing effluent, corn steep liquor, glucose, sucrose and fructose were separately screened for optimal protease production by isolate BPE4. Medium was skimmed milkminimal broth containing (g/L) $\mathrm{MgSO}_{4} .7 \mathrm{H}_{2} \mathrm{O} 0.5$; $\mathrm{K}_{2} \mathrm{HPO}_{4} \quad 1.0 ; \quad \mathrm{KH}_{2} \mathrm{PO}_{4} 1.0$; Skimmed milk $1 \%$; Distilled water $1000 \mathrm{~mL}$; $\mathrm{pH}$ was adjusted to 7.0 with $1 \mathrm{M} \mathrm{HCl}$ and $1 \mathrm{M} \mathrm{NaOH}$. Medium formulation, sterilization and inoculation were as described earlier. Incubation was at room temperature $\left(28 \pm 2^{\circ} \mathrm{C}\right)$ on a rotary shaker agitating at $150 \mathrm{rpm}$ for $36 \mathrm{~h}$. Triplicate protein determinations were made every $3 \mathrm{~h}$. Vibrio fluvialis OWPB63 UCCM 0004 served as positive control while protein reagent (Coomasie brilliant blue solution) was the negative control. A two-factor analysis of variance of data and separation of significant means were conducted with Excel 2007 software to determine the dual influences of carbon source and duration of fermentation on extracellular protease production.

\subsubsection{Effect of nitrogen source on protease production}

Five different nitrogen sources including ammonium chloride, ammonium nitrate, ammonium sulfate, potassium nitrate and sodium nitrate were separately screened for optimal protease production. Medium was skimmed milk-minimal broth containing $(\mathrm{g} / \mathrm{L})$ $\mathrm{MgSO}_{4} .7 \mathrm{H}_{2} \mathrm{O} \quad 0.5 ; \quad \mathrm{K}_{2} \mathrm{HPO}_{4} \quad 1.0 ; \quad \mathrm{KH}_{2} \mathrm{PO}_{4} \quad 1.0$; Skimmed milk 1\%; Filter-sterilized corn steep liquor $1000 \mathrm{~mL} ; \mathrm{pH}$ 7.0. The nitrogen sources were added at $1 \%(\mathrm{w} / \mathrm{v})$ to media. Sterilizations, inoculation, incubation, determinations and analysis were as described in section 2.4.

\subsubsection{Effect of phosphorus source on protease production}

Four different phosphate combinations including $\mathrm{K}_{2} \mathrm{HPO}_{4} / \mathrm{KH}_{2} \mathrm{PO}_{4}, \quad \mathrm{Na}_{2} \mathrm{HPO}_{4} / \mathrm{NaH}_{2} \mathrm{PO}_{4}$, $\mathrm{Na}_{2} \mathrm{HPO}_{4} / \mathrm{KH}_{2} \mathrm{PO}_{4}$ and $\mathrm{K}_{2} \mathrm{HPO}_{4} / \mathrm{NaH}_{2} \mathrm{PO}_{4}$ were separately screened for optimal protease production. Medium was skimmed milk-minimal broth containing $(\mathrm{g} / \mathrm{L}) \quad \mathrm{NH}_{4} \mathrm{NO}_{3} \quad 1.0 ; \mathrm{MgSO}_{4} .7 \mathrm{H}_{2} \mathrm{O} \quad 0.5$; Skimmed milk 1\%; Filter-sterilized corn steep liquor $1000 \mathrm{~mL}$; $\mathrm{pH}$ was adjusted to 7.0 with $1 \mathrm{M} \mathrm{HCl}$ and $1 \mathrm{M} \mathrm{NaOH}$. The phosphate combinations $(2: 1)$ were added at $1 \%(\mathrm{w} / \mathrm{v})$ to media. Sterilizations, inoculation, incubation, determinations and analysis were as described in section 2.4.

\subsubsection{Effect of inoculum size on protease production}

Five different inoculum sizes including $10^{5}, 10^{6}, 10^{7}$, $10^{8}$ and $10^{9}$ cells $/ \mathrm{mL}$ were separately screened for optimal protease production. Inoculum sizes were standardized according to McFarland standards. Medium was skimmed milk-minimal broth containing $(\mathrm{g} / \mathrm{L}) \quad \mathrm{NH}_{4} \mathrm{NO}_{3} 1.0 ; \mathrm{K}_{2} \mathrm{HPO}_{4} / \mathrm{KH}_{2} \mathrm{PO}_{4}$ (2:1) $1.0 ; \mathrm{MgSO}_{4} .7 \mathrm{H}_{2} \mathrm{O}$ 0.5; Skimmed milk $1 \%$; Filter-sterilized corn steep liquor $1000 \mathrm{~mL}$; pH was adjusted to 7.0 with $1 \mathrm{M} \mathrm{HCl}$ and $1 \mathrm{M} \mathrm{NaOH}$. The different inoculum sizes were added at $2 \%(\mathrm{v} / \mathrm{v})$ to media. Sterilizations, inoculation, incubation, determinations and analysis were as described in section 2.4

\subsection{Determination of BPE4 protease activity}

Activity of the test protease was investigated as described in [4] using the non-specific protein, azocasein, as substrate. One unit of protease activity was defined as the amount of crude enzyme required to digest $1 \mathrm{mg}$ of azocasein in one minute under the assay conditions [5].

\subsection{Selection of appropriate temperature for extracellular protease activity}

The effect of temperature on the activity of protease was assessed by measuring the release of trichloroactetic acid (TCA)-soluble peptides from the digestion of azocasein after incubation at temperatures ranging from 5 to $65^{\circ} \mathrm{C}$ for $10 \mathrm{~min}$. Absorbance was measured at $440 \mathrm{~nm}$ in triplicates using a spectrophotometer. Protease activity was calculated using the formula

$E A(U)=C_{a z o} \times V^{2} / t \times v$

where $\mathrm{C}_{\mathrm{azo}}=$ concentration of azocasein derived from the standard curve regression equation $\mathrm{C}_{\mathrm{azo}}(\mathrm{mg} / \mathrm{mL})$ $=-0.5895+22.399 \times$ Absorbance $; \mathrm{V}=$ total volume of reaction mixture; $\mathrm{t}=$ duration of incubation; $\mathrm{v}=$ volume of crude enzyme.

\subsection{Selection of appropriate $\mathrm{pH}$ for} extracellular protease activity

The effect of $\mathrm{pH}$ on the activity of protease was assessed by measuring the release of trichloroactetic acid (TCA)-soluble peptides from the digestion of azocasein after incubation at $\mathrm{pH}$ ranging from 3 to 12 for $10 \mathrm{~min}$. For $\mathrm{pH} 3$ to 6; sodium-phosphate buffer was used; Tris-HCl buffer was used for $\mathrm{pH} 7$ to 8; potassium phosphate buffer for $\mathrm{pH} 9$ to 10 and bicarbonate-phosphate (sodium) buffer for $\mathrm{pH} 11$ to 12. Absorbance was measured at $440 \mathrm{~nm}$ in triplicates using a spectrophotometer. 


\subsection{Effect of substrate on protease activity}

The activity of test protease on different protein substrates was conducted to establish the specificity, or otherwise, of the enzyme. Four protein substrates were used including casein, bovine serum albumin, gelatin and keratin. Activities were monitored at $40^{\circ} \mathrm{C}, \mathrm{pH} 9$ for $30 \mathrm{~min}$. Triplicate determinations were made in all cases.

\section{Results}

The study bacterium, isolated from fermenting bean processing effluent, produced a clear zone of diameter $37.0 \mathrm{~mm}$ on skimmed-milk minimal medium at room temperature within $36 \mathrm{~h}$. The bacterium also elaborated $142.87 \mu \mathrm{g} / \mathrm{mL}$ of crude protease in shake flask experiments within the period.

Results of time course study designed to establish the productivity and possible duration of fermentation by the bacterium revealed that the bacterium produced maximum protease at $36 \mathrm{~h}$. These results, presented in Table 1, also show that peak productivity of the bacterium occurred at $12 \mathrm{~h}$ when the bacterium amassed $32.6 \mu \mathrm{g} / \mathrm{mL}$ of protease within $4 \mathrm{~h}$ giving a peak productivity of $8.18 \mu \mathrm{g} / \mathrm{mL} / \mathrm{h}$. Productivity dropped to 4.55 by the $20^{\text {th }}$ hour only to increase again to $4.66 \mu \mathrm{g} / \mathrm{mL} / \mathrm{h}$ at $24 \mathrm{~h}$. The table shows that protease productivity in the bacterium gradually decreased from this point to the end of the fermentation period of $96 \mathrm{~h}$. Negative protease productivities commenced from $40 \mathrm{~h}$ till the end of fermentation. By $96 \mathrm{~h}$, maximum recoverable protease from fermentation broth was $4.52 \mu \mathrm{g} / \mathrm{mL}$ at a productivity of $-2.75 \mu \mathrm{g} / \mathrm{mL} / \mathrm{h}$. These results set duration of fermentation by this isolate at $36 \mathrm{~h}$.

The sole responsibility of an enzyme is to catalyze a biochemical reaction hence the activity of the enzyme was studied at $30^{\circ} \mathrm{C}$ and $\mathrm{pH} 7$ using the non-specific protease substrate, azocasein, as standard. One unit of proteolytic activity was defined as the amount of crude enzyme that digested $1 \mathrm{mg}$ of azocasein in one minute under the assay conditions of $30^{\circ} \mathrm{C}$ and $\mathrm{pH}$ 7.0. The activity of the crude protease was found to be $100.83 \mathrm{U} / \mathrm{mL}$ after $30 \mathrm{~min}$ of incubation.

The test bacterium, isolate BPE4, was identified by cultural, biochemical, physiological, microscopic and molecular methods involving 16S rRNA gene amplification and sequencing. The results are presented in Table 2. The table shows that the bacterium was catalase and oxidase positive but could not reduce nitrate. Ornithine and lysine were decarboxylated but phenylalanine was not deaminated. A limited number of sugars were utilized including glucose, mannose, fructose and arabinose. The bacterium was defined as a light-yellow, motile, Gram-negative, aerobic, curved rod with $99.4 \%$ sequence homology with Stenotrophomonas acidaminiphila strain AMX 19T and 98.8\% sequence homology with Stenotrophomonas maltophila and Stenotrophomonas nitritireducens. The bacterium was deposited at the University of Calabar Collection of Microorganisms (UCCM).

Results of the evaluation of major medium variables for protease production are presented in Figures 1, 2, 3 and 4. Figure 1 shows that corn steep liquor was the best carbon substrate for protease production by Stenotrophomonas acidaminiphila strain BPE4. The substrate mediated the synthesis of $242.74 \mu \mathrm{g} / \mathrm{mL}$ within $36 \mathrm{~h}$. Other substrates and their protease concentrations were, in descending order, cassava processing effluent $(\mathrm{CPE})-190.67 \mu \mathrm{g} / \mathrm{mL}>$ rice processing effluent (RPE) - $173.24 \mu \mathrm{g} / \mathrm{mL}>$ glucose - $172.56 \mu \mathrm{g} / \mathrm{mL}>$ fructose $-168.43 \mu \mathrm{g} / \mathrm{mL}>$ sucrose $161.80 \mu \mathrm{g} / \mathrm{mL}>$ control $-142.87 \mu \mathrm{g} / \mathrm{mL}$. The control received no extraneous carbon source but skimmed milk served both as carbon and nitrogen sources. The two-factor analysis of variance revealed that both carbon source and fermentation time significantly (carbon source, $P=3.06 \mathrm{E}-30$; fermentation time, $P=$ $7.41 \mathrm{E}-14<0.05)$ influenced protease production.

Figure 2 presents the effect of nitrogen sources on protease production by the bacterium. The figure reveals that ammonium chloride $\left(\mathrm{NH}_{4} \mathrm{Cl}\right)$ was best nitrogen source for the process. This nitrogen source accumulated $267.92 \mu \mathrm{g} / \mathrm{mL}$ of protease in $36 \mathrm{~h}$. $\mathrm{NH}_{4} \mathrm{Cl}$ was followed by $\left(\mathrm{NH}_{4}\right)_{2} \mathrm{SO}_{4}$ which directed the synthesis of $245.76 \mu \mathrm{g} / \mathrm{mL}>$ control - 242.74 $\mu \mathrm{g} / \mathrm{mL}$. The control received no nitrogen source other than the skimmed milk substrate. A two-factor analysis of variance showed significant effects of both nitrogen source and fermentation time (nitrogen source, $P=4.29 \mathrm{E}-20$; fermentation time, $P=3.79 \mathrm{E}-$ $13<0.05)$ on protease production. However, results of the $t$-Test for two samples assuming unequal variances revealed that no significant difference $(P>$ 0.05 ) existed among the three nitrate-nitrogen sources including $\mathrm{NH}_{4} \mathrm{NO}_{3}, \mathrm{KNO}_{3}$ and $\mathrm{NaNO}_{3}$.

Effect of phosphate combinations are presented in Figure 3. The figure shows that $\mathrm{K}_{2} \mathrm{HPO}_{4} / \mathrm{KH}_{2} \mathrm{PO}_{4}$ (2:1) combination, which also served as the control combination, was the best possible phosphate combination for protease production by the bacterium. All other phosphate combinations reduced final protease concentration. Analysis of variance showed that phosphate combinations significantly (phosphate combination, $P=2.02 \mathrm{E}-10$, fermentation time, $P=1.59 \mathrm{E}-19<0.05)$ influenced protease production by the test bacterium.

Results of the influence of inoculum size on protease production are presented as Figure 4. The figure 
Evaluation of the Effects of Nutritional and Environmental Parameters on Extracellular Protease Production by Stenotrophomonas acidaminiphila Strain BPE4

reveals that a starting inoculum size of $10^{8}$ cells $/ \mathrm{mL}$ led to the production of highest amount of protease of $293.67 \mu \mathrm{g} / \mathrm{mL}$ within $36 \mathrm{~h}$ followed by inoculum size of $10^{7}$ cells $/ \mathrm{mL}$ which produced $279.12 \mu \mathrm{g} / \mathrm{mL}$ protease.

Table 1 Time course and protease productivity of BPE4

\begin{tabular}{ccc}
\hline Time $(\mathrm{h})$ & $\begin{array}{c}\text { Mean crude protease concentration } \pm \text { Standard } \\
\text { deviation }(\mu \mathrm{g} / \mathrm{mL})\end{array}$ & Productivity $(\mu \mathrm{g} / \mathrm{mL} / \mathrm{h})$ \\
\hline 0 & $0 \pm 0.00$ & 0 \\
4 & $8.45 \pm 0.82$ & 2.11 \\
8 & $26.52 \pm 1.34$ & 4.52 \\
12 & $59.22 \pm 2.84$ & 8.18 \\
16 & $77.68 \pm 4.32$ & 4.62 \\
20 & $95.88 \pm 4.18$ & 4.55 \\
24 & $114.53 \pm 3.29$ & 4.66 \\
28 & $128.36 \pm 4.15$ & 3.46 \\
32 & $139.52 \pm 7.37$ & 2.79 \\
36 & $142.87 \pm 8.85$ & 0.84 \\
40 & $132.45 \pm 9.56$ & -2.61 \\
44 & $121.65 \pm 6.76$ & -2.70 \\
48 & $110.05 \pm 6.62$ & -2.90 \\
60 & $92.64 \pm 6.72$ & -1.45 \\
72 & $68.53 \pm 4.32$ & -2.01 \\
84 & $37.36 \pm 2.23$ & -2.60 \\
96 & $4.52 \pm 4.52$ & -2.75 \\
\hline
\end{tabular}

Table 2 Biochemical characterization and molecular identification of isolate BPE4

\begin{tabular}{lll}
\hline S/N & Colonial characteristics & \\
\hline 1 & Pigmentation & Light-yellow \\
2 & Consistency & Butyrous \\
3 & Margin & Entire \\
4 & Elevation & Raised \\
5 & Form & Round \\
\hline Microscopic morphology & \\
\hline 6 & Gram reaction & Negative \\
7 & Cell shape & Curved rods \\
8 & Cell size & Less than $0.5 \mu M$ \\
9 & Cell arrangement & Singles \\
10 & Motility & Positive \\
\hline Biochemical characteristics & \\
\hline 11 & Oxidase & Positive \\
12 & Catalase & Positive \\
13 & Hydrogen sulfide production & Positive \\
14 & Phenylalanine deamination & Negative \\
15 & Ornithine decarboxylation & Positive \\
16 & Lysine decarboxylation & Positive \\
17 & Nitrate reduction & Negative \\
18 & Citrate utilization & Negative \\
\hline Sugar utilization & \\
\hline 19 & D-glucose & Positive \\
20 & D-mannose & Positive \\
21 & D-fructose & Positive \\
22 & Lactose & Negative \\
& &
\end{tabular}




$\begin{array}{ll}23 & \text { Arabinose } \\ 24 & \text { Adonitol } \\ 25 & \text { Sorbitol } \\ 26 & \text { 16S rRNA gene amplification and sequencing }\end{array}$

Positive

Negative

Negative

$99.4 \%$ similarity with

Stenotrophomonas acidaminiphila

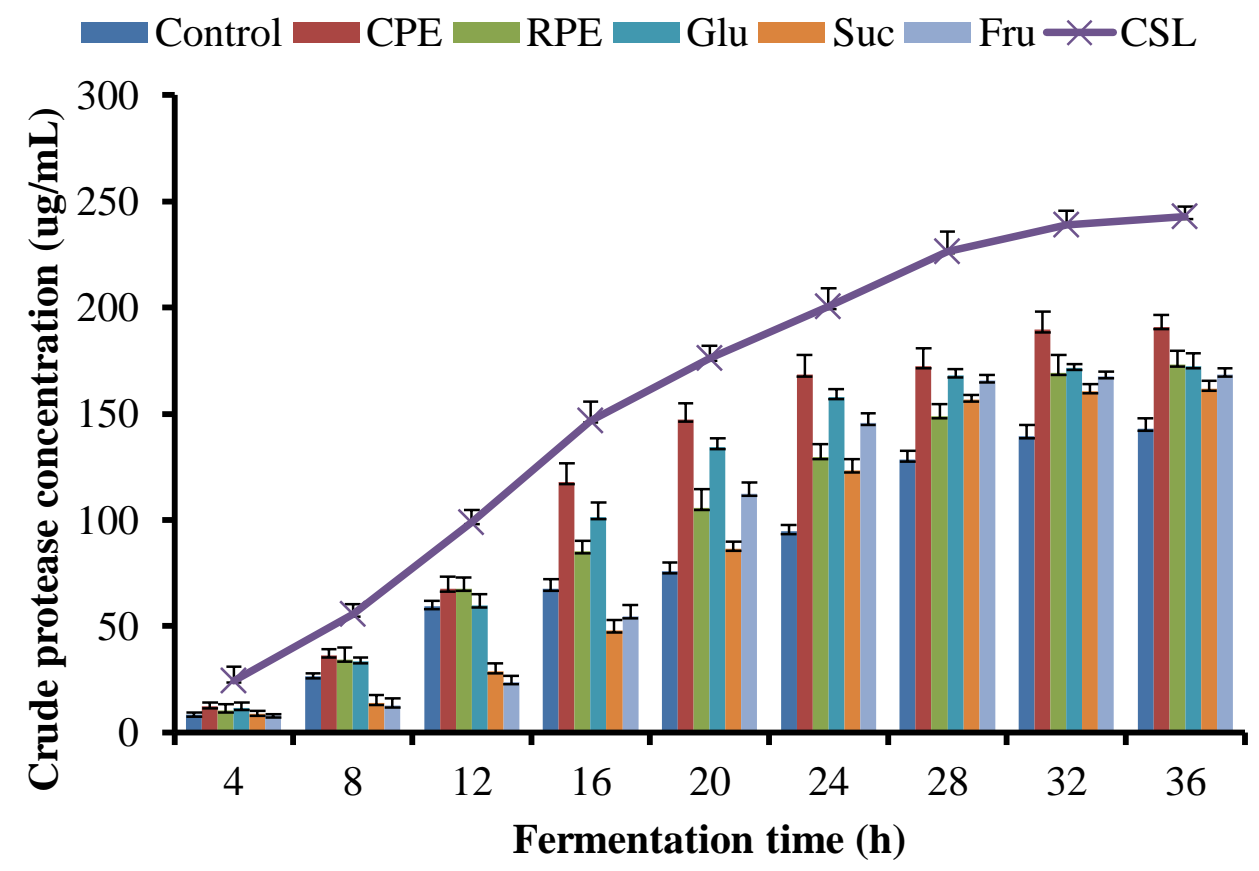

Fig.1 Selection of appropriate carbon source for protease production by Stenotrophomonas acidaminiphila Strain BPE4.

CPE-cassava processing effluent; RPE-rice processing effluent; Glu-glucose; Suc-Sucrose; Fru-fructose; CSL-corn steep liquor

Other inoculum sizes produced protease concentration lower than $267.92 \mu \mathrm{g} / \mathrm{mL}$ of the control. Analysis of variance revealed that inoculum sizes and fermentation time significantly (inoculum size, $P=0.012$; fermentation time, $P=1.45 \mathrm{E}-14<$ 0.05 ) influenced final protease concentration.

Results for the selection of appropriate temperature and $\mathrm{pH}$ for protease activity are presented in Figures 5 and 6 respectively. Figure 5 shows that the most appropriate temperature for enzyme activity was $40^{\circ} \mathrm{C}$, where the enzyme demonstrated highest activity of $122.89 \mathrm{U} / \mathrm{mL}$ at $30 \mathrm{~min}$. This was followed by $111.07 \mathrm{U} / \mathrm{mL}$ and $100.83 \mathrm{U} / \mathrm{mL}$ for $45^{\circ} \mathrm{C}$ and $30^{\circ} \mathrm{C}$ respectively. A two-factor analysis of variance of data showed that temperature and duration of exposure significantly (Temperature, $P=1.31 \mathrm{E}-07$; Time, $P=3.1 \mathrm{E}-05<0.05)$ influenced proteolytic activity. Figure 6 shows that activity of the protease increased with increasing $\mathrm{pH}$ until it peaked at $\mathrm{pH} 9$ from where it declined again.
The activity of an enzyme is intrinsically linked to its substrate and so different protein substrates were screened for activity. The results are presented as Figure 7. The figure shows that casein had the highest relative activity $(\%)$ at $40^{\circ} \mathrm{C}$ and $\mathrm{pH} 9$ for 30 min. None of the remaining three substrates could drive up to $50 \%$ relative activity of the protease.

\section{Discussion}

The test bacterium, strain BPE4, identified by cultural, biochemical, physiological, microscopic and molecular methods involving $16 \mathrm{~S}$ rRNA gene amplification and sequencing as Stenotrophomonas acidaminiphila, was defined as a motile, light-yellow, catalase-positive, oxidase-positive, Gram-negative, aerobic, curved rod with $99.4 \%$ sequence homology with Stenotrophomonas acidaminiphila strain AMX 19T. The bacterium could neither reduce nitrate nor deaminate phenylalanine but could decarboxylate both ornithine and lysine. A limited number of sugars were utilized including glucose, mannose, fructose and arabinose. To the best of our knowledge, this is 
the first report on the potential of this bacterium for protease production.

Productivity; defined, in this study, as the amount of protease released per unit time; was found to reach its peak of $8.18 \mu \mathrm{g} / \mathrm{mL} / \mathrm{h}$ in the study bacterium at $4 \mathrm{~h}$. This implies that the protease is a primary metabolite required for cellular metabolism, primarily for growth and reproduction. The negative values for productivity beyond $36 \mathrm{~h}$ indicate protein turn-over where the enzyme is denatured and possibly degraded into the amino acid building blocks after completing its catalytic role. In a batch mode fermentation for protease production reported by [13], incubation time for protease production was prolonged for $72 \mathrm{~h}$ suggesting the protease to be a secondary metabolite. If the protease was to catalyze the breakdown of a proteolytic substrate to generate simple amino products which would serve as nitrogen source, then cellular metabolism would have been delayed in the organism except there was a readily available inorganic nitrogen source in the medium. On the other hand, the present finding is in agreement with [16] who reported an incubation period of $24 \mathrm{~h}$ for their bacterial strains confirming the primary metabolite (trophophasic) status of the product.

Proteases act on a variety of substrates depending on their nature. The gold standard substrate for evaluation of proteolytic activity has been reported as azocasein owing to its non-specific nature [5]. In this study, one unit of proteolytic activity was defined as the amount of crude enzyme that digested $1 \mathrm{mg}$ of azocasein in one minute under the assay conditions of $30^{\circ} \mathrm{C}$ and $\mathrm{pH}$ 7.0. The activity of the crude protease in this study without recourse to the carbon, nitrogen and phosphorus sources was $100.83 \mathrm{U} / \mathrm{mL}$ or 1680.84 nkat (nanokatal) after $30 \mathrm{~min}$ of incubation. The katal is defined as the amount of enzyme that converts one mole of a substrate in one second. It was recommended by the General Conference on Weights and Measures in 1978 as the standard unit representing enzyme activity because 'minute' is not the SI unit for time. The recommendation was adopted officially in 1999 and the conversion of enzyme activity in $U$ to the katal followed the equation below

[18];

$\begin{array}{lll}\text { Control } & \text { (NH4)2SO4 }\end{array}$

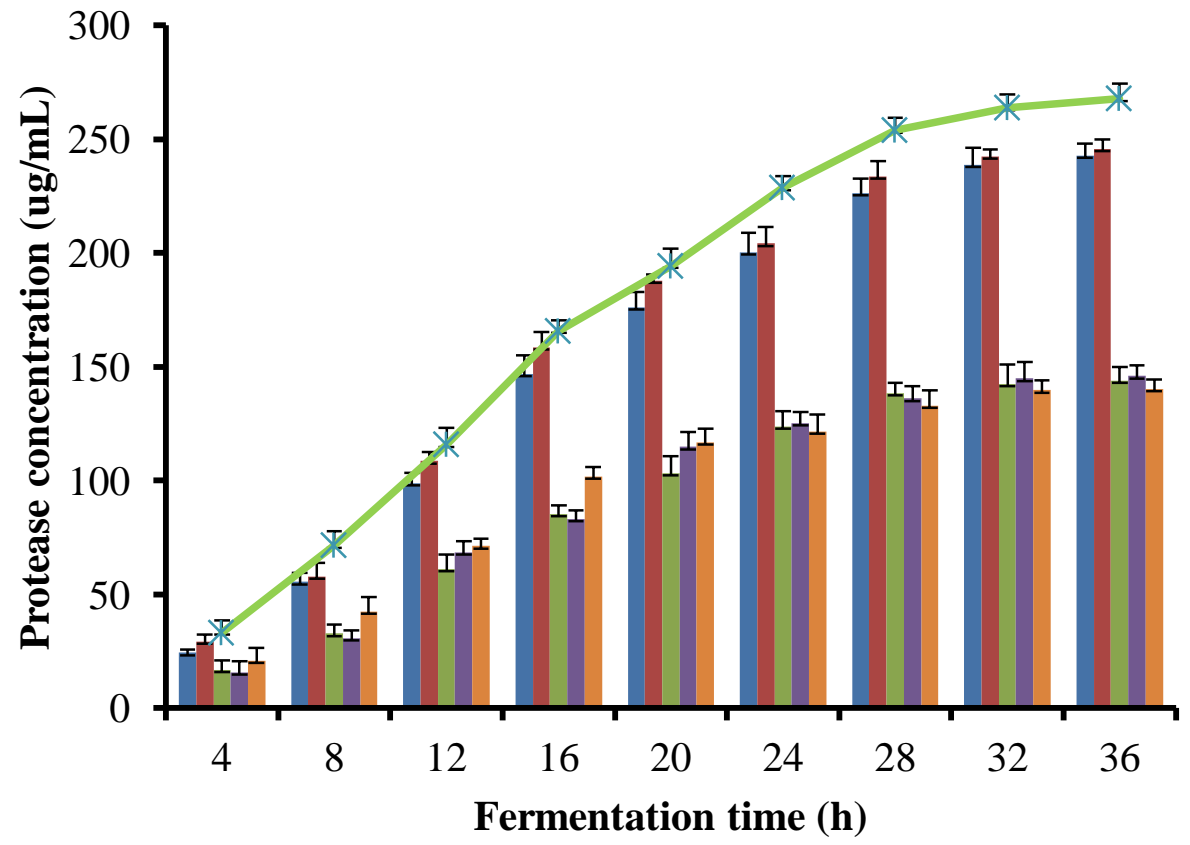

Fig.2 Selection of appropriate nitrogen source for protease production by Stenotrophomonas acidaminiphila strain BPE4 


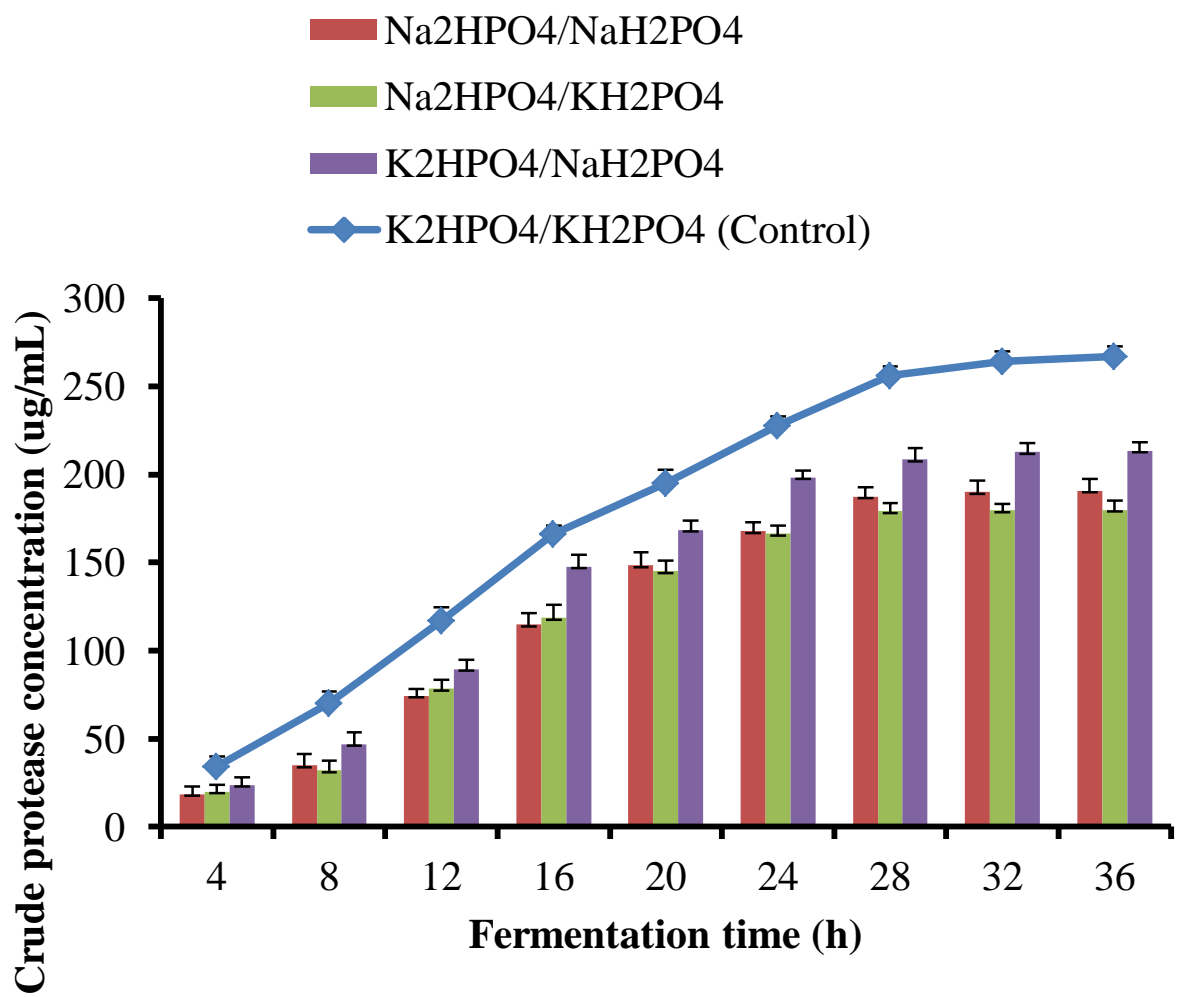

Fig.3 Selection of appropriate phosphate combination for protease production by Stenotrophomonas acidaminiphila strain BPE4

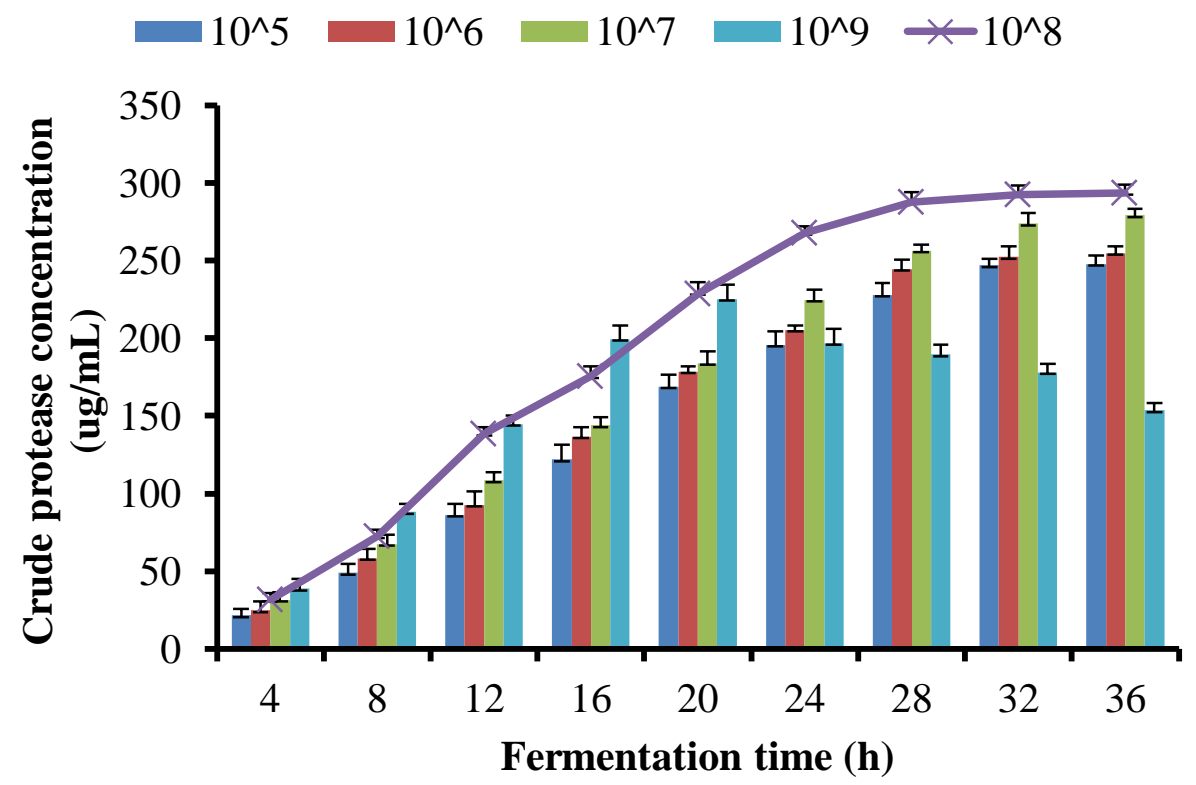

Fig.4 Selection of appropriate inoculum size for protease production by Stenotrophomonas acidaminiphila strain BPE4 


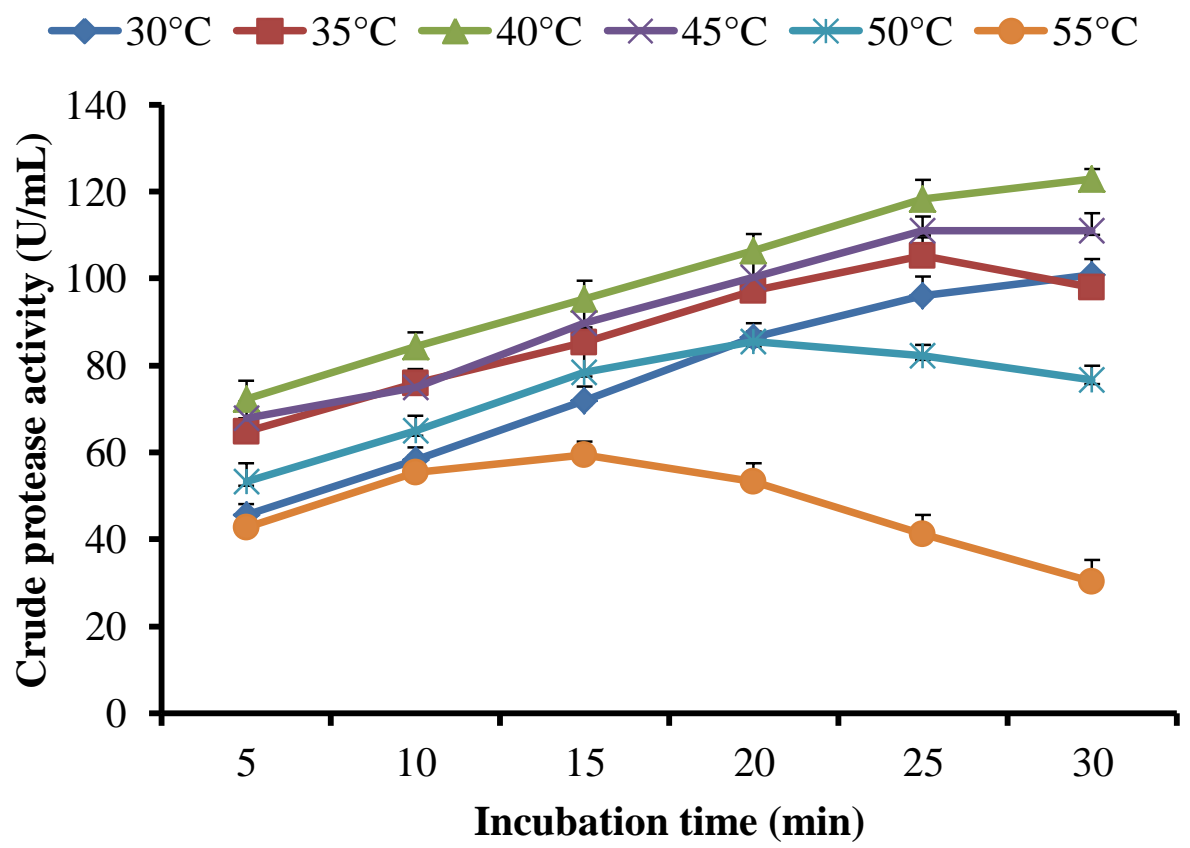

Fig.5 Selection of appropriate temperature for Stenotrophomonas acidaminiphila strain BPE4 protease activity

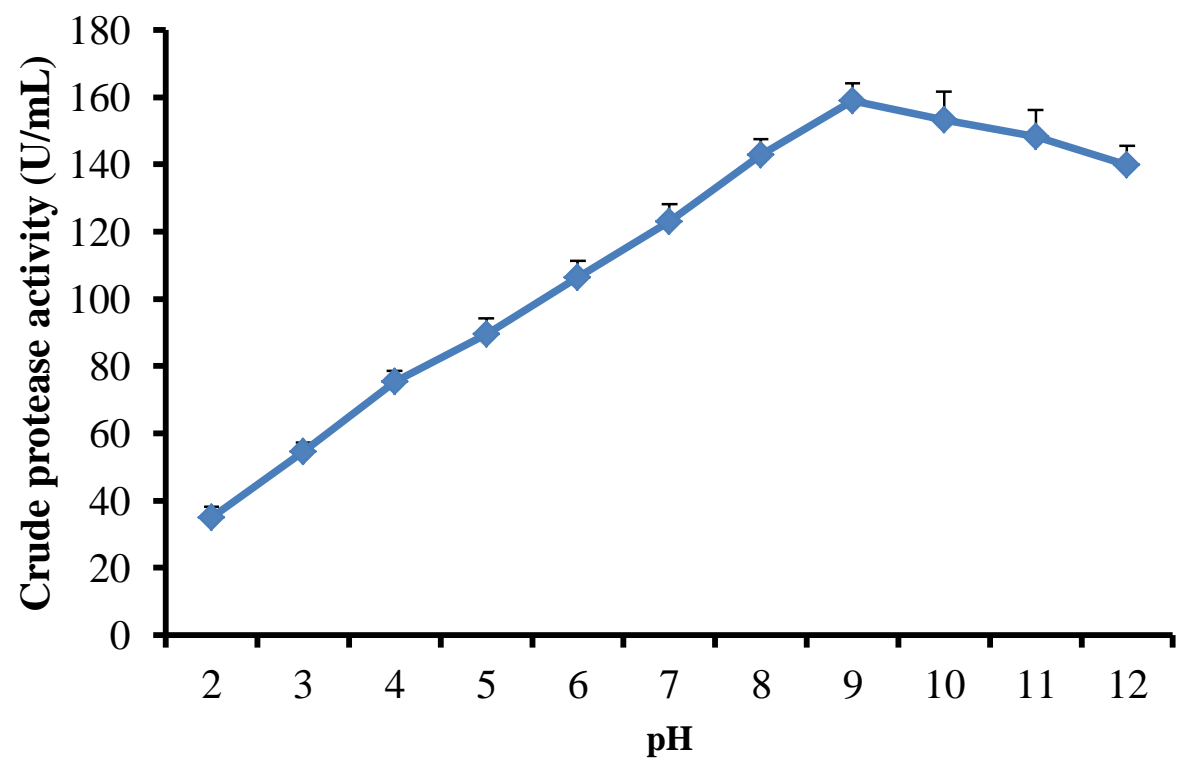

Fig.6 Selection of appropriate $\mathrm{pH}$ for Stenotrophomonas acidaminiphila strain BPE4 protease activity 


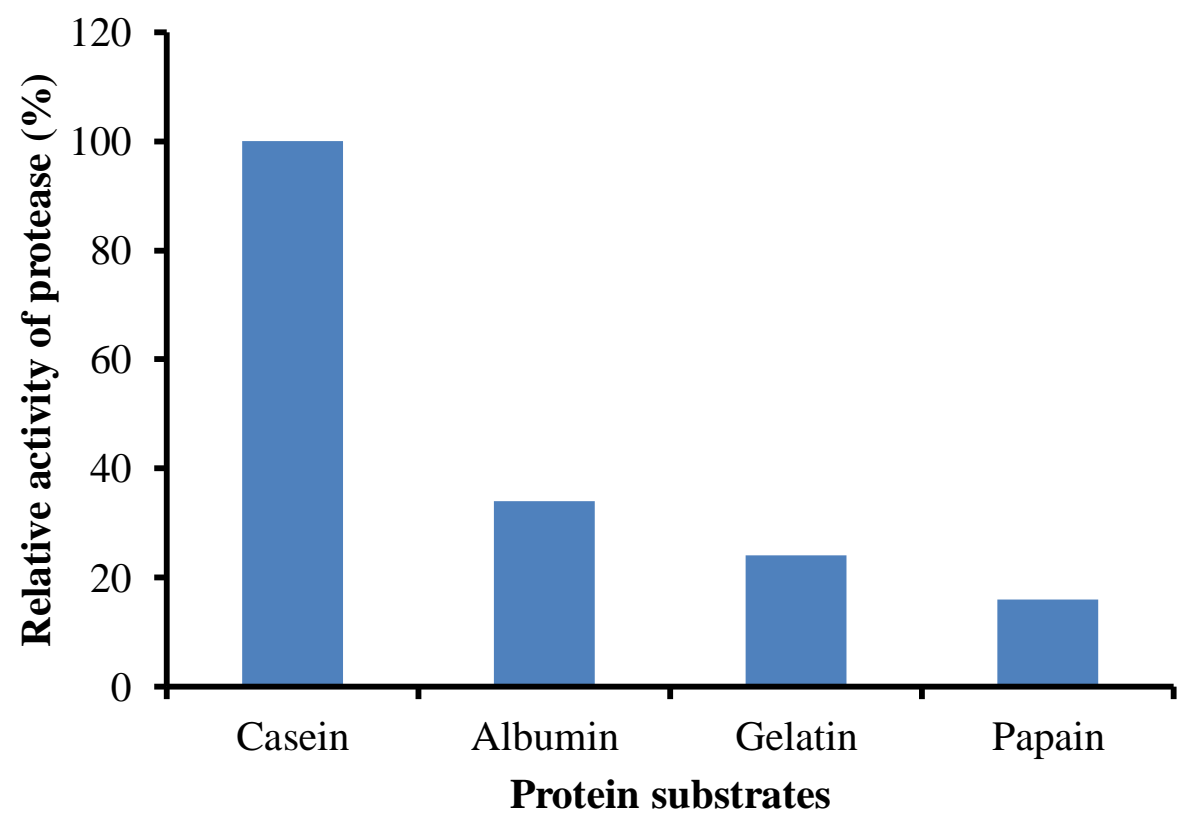

Fig. 7 Effect of substrate on protease activity of Stenotrophomonas acidaminiphila strain BPE4

$U=\frac{1}{1000000} \div 60 \times 1 \mathrm{katal}=\frac{1}{60}$ kkatal $=16.67$ nkatal

Corn steep liquor is a liquid waste obtained from wet corn milling used to produce numerous corn based products that are subsequently used as biofuel, ingredients in food and for livestock feed. These products include starch, high fructose corn syrup, oil, ethanol, bran, gluten feed and meal. Corn steep liquor is one of the by-products of wet corn milling directed to the production of animal feed. It is a mixture of soluble proteins, amino acids, carbohydrates, organic acids (e.g., lactic acid), vitamins and minerals. Microbial biotechnologists employ it as a nutrient for microorganisms in the production of enzymes, antibiotics and other fermentation products. It could serve both as a source of carbon and that of nitrogen. In this study, it was employed as a source of carbon among others, and was selected as best carbon source for protease production by the test bacterium. When soluble starch, glucose, fructose or maltose were separately combined with corn steep liquor (data not shown), protease production by the bacterium was grossly repressed. In Figure 1, protease concentration, mediated by corn steep liquor, is presented as a line made to fly above concentrations mediated by other sources indicating significant preference of the carbon substrate for protease production by the test bacterium. Perhaps extraction of carbon atoms from corn steep substrate for cellular metabolism and energy generation required the expenditure of minimal maintenance energy by the bacterium when compared to other sources of carbon. Its preference could also be attributed its dual role as carbon and nitrogen source.

Production of industrial enzymes in particular and biotechnological products of microbial origin in general, using renewable sources is currently being explored and exploited at different levels all over the world with very commendable results. [17] produced commercial quantities of an alkaline protease from a silk degumming solution; a waste solution from the silk degumming process; using four different strains of Aspergillus flavus and Bacillus licheniformis strain TISTR 1010. In a production optimization experiment, [13] recorded highest predicted alkaline protease activity of $205.2 \mathrm{U} / \mathrm{mL}$ on molasses; a waste substrate from the sugar refining process using Bacillus cereus strain S8. The protease from Stenotrophomonas acidaminiphila strain BPE4 in the present study, however, could demonstrate highest activity of $158.83 \mathrm{U} / \mathrm{mL}$ (2647.70 nkatal) when corn steep liquor served as carbon source. [14] reported successful production of thermostable alkaline protease from Kocuria varians using various agricultural wastes like cow blood meal, fermented cassava wastes, potato, yam and plantain peels, fish meal and corn waste with remarkable success. Exploitation of agro-industrial wastes for production of various value-added microbial metabolites is strongly recommended. 
Nitrogen is required as a major nutrient by microorganisms for the synthesis of amino acids, nitrogenous compounds, nucleic acids and the energy currency, ATP to name a few. These compounds are the major drivers of cellular metabolism leading to biomass accumulation. Oftentimes, in a biotechnological production venture, the nitrogen source adopted for cellular metabolism by an organism differs from the one required for secondary metabolite synthesis $[\mathbf{1}, \mathbf{7}]$. In the present study, the simple readily available, readily assimilable $\mathrm{NH}_{4} \mathrm{Cl}$ was selected for protease production by Stenotrophomonas acidaminiphila strain BPE4. This implies that the initial number of cells needed to elaborate substantial amount of protease for catalytic breakdown of casein was inadequate and the system had to turn to the incorporable form of nitrogen (ammonia- $\mathrm{NH}_{3}$ ) to fulfill this requirement. Once again, the trophophasic status of the product is confirmed. The non-significant difference among the nitrate- $\mathrm{N}_{2}$ sources investigated in the study on protease production by Stenotrophomonas acidaminiphila strain BPE4 is attributable to the inability of the bacterium to reduce the nitratenitrogen sources from the oxidation state of +5 to the incorporable (assimilable) oxidation state of -3 in ammonia. The nitrate- $\mathrm{N}_{2}$ sources were therefore repressive to the synthesis of protease by the bacterium.

Phosphorus plays a dual role in microbial biotechnological productions serving first as a source of phosphorus required for the synthesis of nucleic acids and ATP. Phosphorus sources secondarily serve as buffering systems in fermentation, resisting drastic changes in the $\mathrm{pH}$ of the system thus allowing its continuous operation. A phosphate combination should therefore be employed optimally to fulfill these two requirements. In this investigation, $\mathrm{K}_{2} \mathrm{HPO}_{4} / \mathrm{KH}_{2} \mathrm{PO}_{4} \quad(2: 1)$ combination, which also served as the control combination, was the best possible phosphate combination for protease production by the bacterium. All other phosphate combinations were repressive to protease biosynthesis suggesting that the enzyme was produced in the trophophase of bacterial growth.

The driving reactants in microbial fermentations are the microorganisms themselves and their number by volume is an important control point in fermentation. Only a handful of researches report the number of microbial cells involved in a production study. [7] reported that $10^{8}$ cells $/ \mathrm{mL}$ were required to drive biosurfactant production by Pseudomonas aeruginosa strain IKW1 to completion. [14] reported $10^{3}$ cells $/ \mathrm{mL}$ as the inoculum size required for protease production in Kocuria varians using various agricultural wastes. [2] used an inoculum size that produced an optical density of 0.5 at $660 \mathrm{~nm}$ wavelength for the production of thermostable organic-solvent tolerant protease by a halotolerant Bacillus subtilis strain Rand. In this study, an inoculum size of $10^{8}$ cells $/ \mathrm{mL}$ was selected for protease production. [7] argued that selection of this optimal inoculum size suggests that too little an initial cell population would delay metabolite production until such a time that its density reached the desired quorum and that too large an initial cell population might arrest production too early by reason of ineffective collisions between the bacterial cells (catalysts) and the substrates for want of space in a saturated system.

The influence of environmental factors like temperature and $\mathrm{pH}$ on enzyme activity has been copiously documented. It should be understood that optimum temperature for production is very different from that for activity of the enzyme. In this study, optimum temperature for protease activity was $40^{\circ} \mathrm{C}$ as against the room temperature adopted for production. This casts doubts on reports of enzyme activities obtained during the production or fermentation process. There would be better agreement in literature if enzyme activity reports are results of activities after finding optimum conditions and specific substrates. At the optimum temperature, the activity of the enzyme will not be at its peak until the $\mathrm{pH}$ is equally at its optimum. In this study, at the optimum temperature of $40^{\circ} \mathrm{C}$, protease activity was $122.89 \mathrm{U} / \mathrm{mL}$ ( 2048.58 nkatal) at $\mathrm{pH} 7.0$, but at the optimum $\mathrm{pH}$ of 9.0 selected, protease activity increased to $158.83 \mathrm{U} / \mathrm{mL}(2647.70$ nkatal) at the optimum temperature. When substrates other than casein were employed in the assay, relative activity of the enzyme decreased tremendously (Figure 7) suggesting that the enzyme is a caseinolytic protease.

\section{Conclusion}

An unusual protease producing bacterium Stenotrophomonas acidaminiphila isolated from fermenting bean effluent was reported in this study. The bacterium produced protease copiously using corn steep liquor as carbon source in the trophophase of growth. Optimal conditions of temperature and $\mathrm{pH}$ were set at $40^{\circ} \mathrm{C}$ and 9.0 respectively. The protease activity was maximal when casein served as the protein substrate.

\section{References}

1. Abalos, A., Maximo, F., Manresa, M.A. and Bastida, J. (2002). Utilization of response surface methodology to optimize the culture media for the production of rhamnolipids by Pseudomonas aeruginosa AT10. Journal of Chemical Technology and Biotechnology, 77: 777784.https://doi.org/10.1002/jctb.637 
2. 2. Abusham, R. A., Rahman, R. N. Z., Salleh, A. B. and Basri, M. (2009). Optimization of physical factors affecting the production of thermo-stable organic solvent-tolerant protease from a newly isolated halotolerant Bacillus subtilis strain Rand. Microbial Cell Factories, 8: 20-28. https://doi.org/10.1186/1475-2859-8-20

3. Arshad, M. S., Kwon, J-H., Imran, M., Sohaib, M., Aslam, A., Nawaz, I., Amjad, Z., Khan, U. and Javed, M. (2016). Plant and bacterial proteases: A key towards improving meat tenderization, a mini review. Cogent Food and Agriculture, 2: 1261780. https://doi.org/10.1080/23311932.2016.1261780

4. Asitok, A. D., Antai, S. P. and Ekpenyong, M. G. (2017). Water soluble fraction of crude oil uncouples protease biosynthesis and activity in hydrocarbonoclastic bacteria; implications for natural attenuation. International Journal of Sciences, 6 (7) 5-21. http://dx.doi.org/10.18483/ijSci.1344

5. Coêlho, D. F., Saturnino, T. P., Fernandes, F. F., Mazzola, P. G., Silveira, E. and Tambourgi, E. B. (2016). Azocasein substrate for determination of proteolytic activity: reexamining a traditional method using bromelain samples. Biomed Research International. https://doi.org/10.1155/2016/8409183

6. Dalbey, R. E., Wang, P. and van Dijlb, J. M. (2012). Membrane proteases in the bacterial protein secretion and quality control pathway. Microbiology and Molecular Biology Reviews, 76: 311-330. https://doi.org/10.1128/MMBR.05019-11

7. Ekpenyong, M., Antai, S., Asitok, A. and Ekpo, B. (2017). Response surface modeling and optimization of major medium variables for glycolipopeptide production. Biocatalysis and Agricultural Biotechnology, 10: 113-121. https://doi.org/10.1016/j.bcab.2017.02.015

8. Gupta, R. G., Beg, Q. K. and Lorenz, P. (2002). Bacterial alkaline proteases: Molecular approaches and industrial applications. Applied Microbiology and Biotechnology, 59: 15-32. https://doi.org/10.1007/s00253-002-0975-y

9. Holt, J. G., Krieg, N. R., Sneath, P. H. A., Staley, J. T. and Williams, S. T. (1994). Bergey's Manual of Determinative
Bacteriology, Hensyl, W. R. (ed.) 9th edition. Maryland: Williams and Williams.

10. Iboyo, A. E., Asitok, A. D., Ekpenyong, M. G. and Antai, S. P. (2017). Selection of Enterobacter cloacae strain POPE6 for fermentative production of extracellular lipase on palm kernel oil processing effluent. International Journal of Sciences, 6: (11) 1-17. https://doi.org/10.18483/ijSci.1482

11. Jeyadharshan, V. N. (2013). Production and partial purification of protease by Actinomyces species. International Journal of Scientific and Research Publications, 3: 1-3

12. . Jisha, V. N., Smitha, R. B., Pradeep, S., Sreedevi, S., Unni, K. N., Sajith, S., Priji, P., Josh, M. S. and Benjamin, S. (2013). Versatility of microbial proteases. Advances in Enzyme Research, 1: 39-51. https://doi.org/10.4236/aer.2013.13005

13. Lakshmi B. K. M and Hemalatha K. P. J. (2015). Response surface optimization of medium composition for alkaline protease production by Bacillus cereus strain S8. International Journal of Pure and Applied Bioscience, 3: 216-223.

14. Nwagu, T. N., Nomeh, N. and Amadi, O. C. (2015). Production of a thermostable alkaline protease from alkalophilic Kocuria varians grown on various agricultural wastes. Acta Alimentaria, 44: 317-325. https://doi.org/10.1556/AAlim.2014.0008

15. Sawant, R and Nagendran, S. (2014). Protease: an enzyme with multiple industrial applications. World Journal of Pharmacy and Pharmaceutical Sciences, 3: 568-579

16. Singh, P., Rani, A. and Chaudhary, N. (2015). Isolation and characterization of protease producing Bacillus sp. from soil. International of Pharma Sciences and Research, 6: 633-639

17. Vaithanomsat, P., Malapant, T. and Apiwattanapiwat, W. (2008). Silk degumming solution as substrate for microbial protease production. Kasetsart Journal (Nature Science) 42: $543-551$

18. Wharton, C. W. and Eisenthal, R. (2013). Molecular Enzymology. Springer Science Business Media 